\title{
Remifentanil post-conditioning attenuates cardiac ischemia-reperfusion injury via $\kappa$ or $\delta$ opioid receptor activation
}

\author{
G. T. C. Wong, R. Li, L. L. JiAnG and M. G. IRWIN \\ Department of Anaesthesiology, University of Hong Kong, Hong Kong
}

\begin{abstract}
Background: Ischemic pre- or post-conditioning of the heart has been shown to involve opioid receptors. Remifentanil, an ultra-short-acting selective $\mu$ opioid receptor agonist in clinical use, pre-conditions the rat heart against ischemia-reperfusion injury. This study investigates whether remifentanil post-conditioning is also cardioprotective.

Methods: Remifentanil post-conditioning (5-min infusion at $1.5,10-20 \mu \mathrm{g} / \mathrm{kg} / \mathrm{min}$ ) or ischemic post-conditioning (three cycles of a $10 \mathrm{~s}$ reperfusion interspersed with a $10 \mathrm{~s}$ ischemia) was induced in an open-chest rat heart model of ischemia and reperfusion injury, in the presence or absence of nor-binaltorphimine, naltrindole or CTOP, specific $\kappa, \delta$ and $\mu$ opioid receptor antagonists, respectively. The same sequence of experiments was repeated in the isolated heart model using the maximal protective dose of remifentanil from the dose-response studies.

Results: Both ischemic and remifentanil post-conditioning reduced the myocardial infarct size relative to the control
\end{abstract}

group in both models. This cardioprotective effect for both post-conditioning regimes was prevented by the prior administration of nor-binaltorphimine and naltrindole but not CTOP. The sole administration of the antagonists had no effect on the size of myocardial infarction.

Conclusions: These results indicate that remifentanil post-conditioning protects the heart from ischemia-reperfusion injury to a similar extent as of ischemic postconditioning. This protection involves $\kappa$ and $\delta$ but not $\mu$ opioid receptor activation. This drug has great potential as a clinical post-conditioning modality as it can be given in large doses without prolonged opioid-related side effects.

Accepted for publication 15 September 2009

(C) 2009 The Authors

Journal compilation (C) 2009 The Acta Anaesthesiologica Scandinavica Foundation
C ARDIAC post-conditioning refers to therapeutic maneuvers administered just before final reperfusion that attenuate ischemia-reperfusion injury. Ischemic post-conditioning involving staccato reperfusion reduces infarct size (IS) to an extent comparable to that achieved by pre-conditioning, ${ }^{1}$ and molecular studies have implicated several common components and pathways. ${ }^{2}$ Opioid receptors are involved in ischemic post-conditioning, as the latter can be blocked by the peripherally restricted opioid antagonist naloxone methiodide ${ }^{3}$ and the $\delta$-specific antagonist naltrindole (NTD). ${ }^{4}$ Not until recently has the role of $\mu$ receptors in post-conditioning been specifically addressed ${ }^{5}$ as it has traditionally been thought to be absent from the heart, ${ }^{6}$ although more recent binding studies have challenged this. ${ }^{7}$

Remifentanil, a selective $\mu$ agonist, pre-conditions the heart in the intact rat in part via $\mu$ receptor activation, possibly in a location outside the heart. ${ }^{8,9}$ As common reperfusion injury salvage pathways may be triggered by pre- and post-conditioning, ${ }^{10}$ remifentanil could potentially post-condition the myocardium. This study, evaluates whether remifentanil is cardioprotective when administered in a post-conditioning fashion and compares its effect with that of ischemic post-conditioning. The relative role of opioid receptor subtypes in both regimes was also investigated by the use of subtype-specific opioid receptor antagonists.

\section{Material and methods}

All procedures were approved by the local Committee for the use of live animals in teaching and research. Experiments were conducted using 8-week-old male Sprague-Dawley rats weighing

\begin{tabular}{|cc|l|}
\hline Dispatch: 13.10 .09 & Journal: AAS & CE: Deepika/Shwetha \\
\hline Author Received: & No. of pages: 9 & PE: Bindu/Mini \\
\hline
\end{tabular}


$300 \pm 25 \mathrm{~g}$, which were housed in separate cages, given free access to food and water, except before the study, and were exposed to alternate 12-h light and dark cycles. A total of 114 animals were used for in the vivo and 74 for the isolated heart experiments.

\section{In vivo induction of ischemia-reperfusion injury} An anesthetized open-chest model of ischemia and reperfusion injury was used. The anesthetic and surgical preparation to the point of post-conditioning and the IS determination have been described in detail previously. ${ }^{11}$ In short, anesthesia was induced using pentobarbitone $(50 \mathrm{mg} / \mathrm{kg})$ and maintained with boluses of $25 \mathrm{mg} / \mathrm{kg} 90 \mathrm{~min}$ after induction. The heart was exposed via left thoracotomy at the fifth intercostal space. Repeated cycles of regional ischemia and reperfusion were made by tightening or releasing the snare placed at the origin of the left coronary artery. More prolonged ischemia involved securing the sutures with a mosquito hemostat. Ischemia was confirmed by cardiac cyanosis, a substantial decrease in the mean arterial pressure and electrocardiographic changes.

\section{Isolated rat heart preparation}

After the removal from the anesthetized rat, the heart was immediately perfused by the Langendorff method, and subsequently converted to the working heart model (preload $15 \mathrm{cmH}_{2} \mathrm{O}$, afterload $80 \mathrm{cmH}_{2} \mathrm{O}$ ). Modified Krebs-Henseleit bicarbonate buffer was used as the perfusion buffer $(\mathrm{K}-\mathrm{H}$ buffer, mM: $\mathrm{NaCl} 118, \mathrm{KCl} 4.7, \mathrm{CaCl}_{2} 2.0, \mathrm{MgSO}_{4}$ $1.2, \mathrm{KH}_{2} \mathrm{PO}_{4} 1.2$, EDTA 0.5, $\mathrm{NaHCO}_{3} 25$, glucose 11, $\mathrm{pH} 7.4,37^{\circ} \mathrm{C}, 95 \% \quad \mathrm{O}_{2}+5 \% \quad \mathrm{CO}_{2}$ gas mixture). Electrocardiograms and indices of left ventricular performance pressure [left ventricular developed pressure (LVDP), left ventricular end diastolic pressure (LVEDP), positive and negative maximum left ventricular pressure derivative $(+\mathrm{d} P / \mathrm{d} t$ and $-\mathrm{d} P / \mathrm{d} t)]$ were measured using a Power-Lab monitoring system with a Mikro-Tip Pressure Catheter (AD Instruments, Colorado Springs, CO). After an initial stabilization period of $15 \mathrm{~min}$, ligation of the left coronary artery was performed using a 6-0 prolene loop, along with a snare occluder, to mimic a regional ischemia condition for $30 \mathrm{~min}$, followed by $120 \mathrm{~min}$ of reperfusion.

\section{Myocardial IS determination}

After the $120 \mathrm{~min}$ of reperfusion, the hearts from the in vivo were excised and transferred to a
Langendorff apparatus. Each heart was immediately perfused with normal saline for $1 \mathrm{~min}$ at a pressure of $100 \mathrm{cmH}_{2} \mathrm{O}$ to remove residual blood. The left coronary artery was re-occluded and $0.25 \%$ Evans blue dye was injected to stain the normally perfused region of the heart. Evans blue negative area represented the area at risk (AAR) from occlusion of the left coronary artery. The hearts were then frozen, cut into $2 \mathrm{~mm}$ slices, incubated at $37^{\circ} \mathrm{C}$ for $20 \mathrm{~min}$ in $1 \%$ 2, 3, 5-triphenyltetrazolium (Sigma Chemical Company, St Louis, MO) in phosphate buffer at $\mathrm{pH} 7.4$ and then immersed in 10\% formalin for $20 \mathrm{~min}$ to enhance the contrast of the stain. The areas of infarct (triphenyltetrazolium negative) and the risk zone for each slice were traced and digitized using a computerized-planimetry technique (SigmaScan 4.0, Systat Software Inc., Richmond, CA). The volumes of the left ventricles, IS and AAR were calculated by multiplying area with slice thickness and summing the product. The IS was expressed as a percentage of the AAR (IS/AAR), and this ratio was used to compare the differences between the groups.

\section{Treatment protocols (Fig. 1)}

Intact animal studies. All animals were subjected to $30 \mathrm{~min}$ of ischemia, followed by $120 \mathrm{~min}$ of reperfusion. Rats were omitted from further data analysis if severe hypotension (arterial mean blood pressure $<30 \mathrm{mmHg}$ ) or intractable ventricular fibrillation occurred. At $5 \mathrm{~min}$ before the onset of reperfusion, the animals were allocated to different treatments according to a predetermined randomized sequence. All the drugs used were dissolved in normal saline for administration.

Dose-response studies. For a negative control group, normal saline was infused for a period of $5 \mathrm{~min}$ beginning just before reperfusion. Remifentanil post-conditioning was evaluated using a 5-min infusion of the drug at $1,5,10$ or $20 \mu \mathrm{g} / \mathrm{kg} / \mathrm{min}$ of body weight (GlaxoSmithKline Limited, Hong Kong, Hong Kong). In order to achieve nearsteady-state levels at reperfusion, the infusion was commenced $5 \mathrm{~min}$ before the release of the snare occluder. For a positive control, ischemic post-conditioning was used and comprised of three cycles of $10 \mathrm{~s}$ of reperfusion and $10 \mathrm{~s}$ of ischemia before the final reperfusion.

This regime was chosen based on previous studies in a rat model that was shown to be effective. ${ }^{12,13}$ The remifentanil dose at which max- 
Fig. 1. Study design for in vivo and isolated heart preparation experiments. Ischemia-reperfusion injury was induced by 30 min of left coronary artery ligation, followed by 120 min of reperfusion. CON, control; Ipoc, ischemic post-conditioning (three cycles of $10 \mathrm{~s}$ of ischemia alternating with 10 s of reperfusion); Repoc, remifentanil post-conditioning $(1,5,10$ or $20 \mu \mathrm{g} / \mathrm{kg} / \mathrm{min}) ; \mathrm{NTD}$, naltrindole; nor $B N I$, nor-binaltorphimine and CTOP, D-Phe-Cys-Tyr-D-Trp-Orn-Thr-Pen$\mathrm{Thr}-\mathrm{NH}_{2}$.
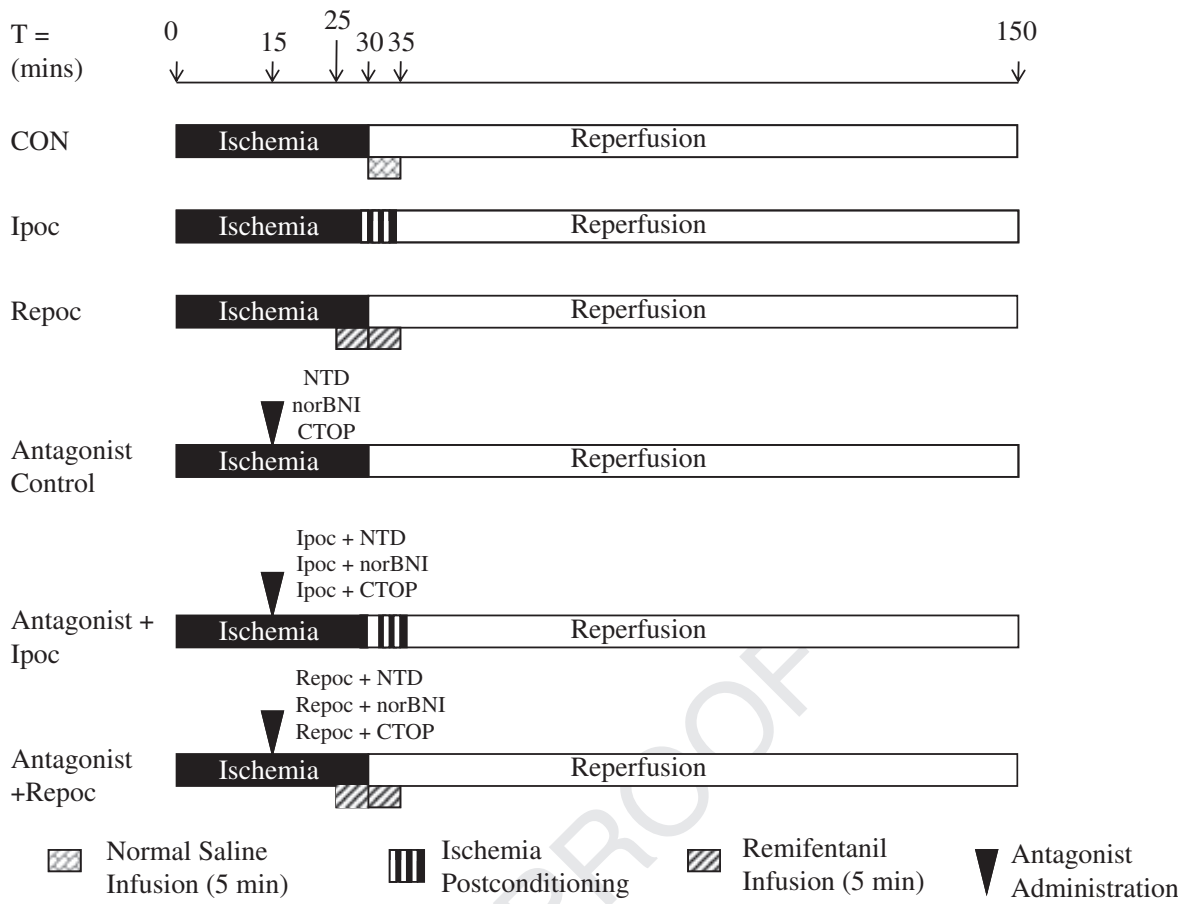

imal protection occurred was selected for the antagonists and isolated heart studies.

Antagonist studies. Each of the antagonists was given $15 \mathrm{~min}$ before reperfusion to evaluate any intrinsic effects they may have had on myocardial IS. These compounds were NTD, a $\delta$ opioid receptor selective antagonist, ${ }^{14}$ D-Phe-Cys-Tyr-DTrp-Orn-Thr-Pen-Thr-NH $\mathrm{NH}_{2}$ (CTOP), a $\mu$ opioid receptor selective antagonist, ${ }^{15}$ and nor-binaltorphimine (nor-BNI), a $\kappa$ opioid receptor selective antagonist $^{16}$ (Sigma Chemical Company). These selective opioid receptor antagonists were dissolved in normal saline and administered as a bolus at the following doses: NTD $(5 \mathrm{mg} / \mathrm{kg})$; nor BNI $(5 \mathrm{mg} / \mathrm{kg})$ and CTOP $(1 \mathrm{mg} / \mathrm{kg})$. Both ischemic post-conditioning and remifentanil post-conditioning $(20 \mu \mathrm{g} / \mathrm{kg} / \mathrm{min})$ were then performed in the presence of individual antagonists administered $15 \mathrm{~min}$ before reperfusion.

Isolated heart studies. The same sequences of experiments were performed in the isolated heart subjected to simulated ischemia and reperfusion. Only the dose of remifentanil that produced the maximal reduction of IS in the intact animal was used in the isolated heart study. Although it is unlikely that remifentanil will reach the ischemic myocardium, it was introduced $5 \mathrm{~min}$ before reperfusion to mimic the in vivo preparation and continued for $5 \mathrm{~min}$ after the release of the snare occlude.

\section{Statistical analysis}

The primary outcome is myocardial IS, expressed as percentage of the area at risk (IS/AAR). Previous data from our laboratory using this model of cardiac ischemia-reperfusion injury indicated the expected IS/AAR of the control group to be between $50 \%$ and $60 \%$ and the expected magnitude of IS/AAR reduction to be $40-50 \%$. Therefore, at least five animals per group are required to yield a power of $80 \%$ and a $P$-value of 0.05 . All data are expressed as mean $\pm \mathrm{SD}$, and were obtained from six to seven separate animals per group. Statistical significance was determined by one-way analysis of variance (ANOVA), with application of Bonferroni correction if significant $F$ ratios were obtained. Hemodynamic data were analyzed using one-way ANOVA for between-group comparisons and repeated measure ANOVA for comparisons between time points (SPSS version 16.0 for windows).

\section{Results}

A total of 114 animals completed the in vivo experiments. Nineteen rats were excluded from further analysis as they developed refractory hypotension $(n=4)$ and ventricular fibrillation $(n=15)$ during the induction of regional ischemia. They have yet received any experimental drugs. A total of 74 rats were used for the isolated heart preparations. 


\section{G. T. C. Wong et al.}

In vivo hemodynamic data

The hemodynamic data for the dose-response studies are presented in Table 1, and those for the antagonist experiments are presented in Table 2. Hemodynamic values including heart rate (HR), mean arterial blood pressure (MAP) and ratepressure product (RPP) did not differ between groups $(P>0.05)$ at baseline at the end of the ischemic or reperfusion periods for both series of experiments. For the dose-response experiments, remifentanil post-conditioning reduced the HR and $\mathrm{RPP}$, except for the $10 \mu \mathrm{g} / \mathrm{kg}$ dose. Both the 5 and the $20 \mu \mathrm{g} / \mathrm{kg} / \mathrm{min}$ dose reduced the MAP. In the antagonist experiments, the HR and RPP in all the groups were also significantly lower during postconditioning compared with the control group, with the MAP reduced only in the remifentanilcontaining groups.

\section{In vivo IS comparisons}

The AAR ranged from $0.36 \pm 0.02$ to $0.44 \pm 0.03 \mathrm{~cm}^{3}$ and there were no significant differences between the treatment groups. The IS/AAR was reduced by remifentanil post-conditioning at doses of $10 \mu \mathrm{g} /$ $\mathrm{kg} / \mathrm{min}(40 \pm 4 \%)$ and $20 \mu \mathrm{g} / \mathrm{kg} / \mathrm{min}(39 \pm 6 \%)$, as well as ischemic post-conditioning $(40 \pm 6 \%)$ when compared with the control group (55 $\pm 7 \%)$ $(P<0.05)$ (Fig. 2). Although there was a reduction in IS/AAR using $5 \mu \mathrm{g} / \mathrm{kg} / \mathrm{min}(45 . \pm 6 \%)$, it did not reach statistical significance when compared with the control $(P=0.07)$. However, there was no difference in the infarct-sparing effect between the two modes of post-conditioning $(P=1.0)$. The addition of NTD or nor-BNI before both ischemic and remifentanil pre-conditioning prevented their protective effects. However, CTOP had no significant effect on either post-conditioning regime. The sole administration of individual opioid receptor antagonists did not change the IS compared with the control (Fig. 3).

\section{Hemodynamic indices in the isolated heart}

The HR and indices of left ventricular performance are presented in Table 3. There were no differences between groups at baseline, during ischemia, at 60 and $120 \mathrm{~min}$ after reperfusion for all indices. There were also no differences between groups for the positive and negative $\mathrm{d} p / \mathrm{d} t$ values for all time points. Remifentanil post-conditioning reduced the LVDP, LVEDP and HR at 10 min after reperfusion. Repoc + nor-BNI reduced LVDP and HR at 10 min after reperfusion, whereas Repoc +NTD and

Table 1

Hemodynamic data of the dose response studies.

\begin{tabular}{|c|c|c|c|c|c|}
\hline & $n$ & Baseline & Ischemia & Post-conditioning & Reperfusion \\
\hline \multicolumn{6}{|l|}{ MAP (mmHg) } \\
\hline CON & 6 & $99 \pm 11$ & $96 \pm 10$ & $93 \pm 10$ & $77 \pm 16^{*}$ \\
\hline IPOC & 6 & $107 \pm 9$ & $102 \pm 11$ & $81 \pm 3^{*}$ & $90 \pm 10^{*}$ \\
\hline Repoc 1 & 6 & $121 \pm 21$ & $80 \pm 16^{*}$ & $71 \pm 20^{*}$ & $93 \pm 15$ \\
\hline Repoc 5 & 6 & $107 \pm 12$ & $77 \pm 8^{*}$ & $63 \pm 18^{*}$ & $83 \pm 18$ \\
\hline Repoc 10 & 6 & $122 \pm 24$ & $93 \pm 19^{*}$ & $73 \pm 22^{*}$ & $102 \pm 19$ \\
\hline Repoc 20 & 7 & $103 \pm 5$ & $97 \pm 11$ & $65 \pm 8^{*}, \dagger$ & $88 \pm 11$ \\
\hline \multicolumn{6}{|c|}{ HR (per minute) } \\
\hline CON & 6 & $423 \pm 24$ & $406 \pm 12$ & $413 \pm 18$ & $368 \pm 21^{*}$ \\
\hline IPOC & 6 & $423 \pm 21$ & $416 \pm 19$ & $373 \pm 14^{*}$ & $390 \pm 14^{*}$ \\
\hline Repoc 1 & 6 & $378 \pm 46$ & $377 \pm 44$ & $323 \pm 40 \dagger$ & $341 \pm 39$ \\
\hline Repoc 5 & 6 & $392 \pm 34$ & $396 \pm 25$ & $353 \pm 50 \dagger$ & $325 \pm 23$ \\
\hline Repoc 10 & 6 & $380 \pm 48$ & $382 \pm 57$ & $370 \pm 31$ & $366 \pm 52$ \\
\hline Repoc 20 & 7 & $417 \pm 21$ & $408 \pm 16$ & $345 \pm 14^{*}, \dagger$ & $385 \pm 19$ \\
\hline \multicolumn{6}{|c|}{$\operatorname{RPP}(\mathrm{mmHg} / \mathrm{min} / 1000)$} \\
\hline CON & 6 & $42 \pm 4$ & $39 \pm 4$ & $38 \pm 4$ & $28 \pm 6^{\star}$ \\
\hline IPOC & 6 & $45 \pm 4$ & $43 \pm 3$ & $30 \pm 2^{*}$ & $34 \pm 4^{*}$ \\
\hline Repoc 1 & 6 & $45 \pm 9$ & $30 \pm 6^{*}$ & $23 \pm 8^{*}, \dagger$ & $32 \pm 7^{*}$ \\
\hline Repoc 5 & 6 & $42 \pm 4$ & $31 \pm 5^{\star}$ & $23 \pm 9^{*}, \dagger$ & $27 \pm 7^{*}$ \\
\hline Repoc 10 & 6 & $46 \pm 9$ & $36 \pm 10^{*}$ & $27 \pm 10^{*}$ & $38 \pm 11$ \\
\hline Repoc 20 & 7 & $42 \pm 4$ & $39 \pm 5^{*}$ & $22 \pm 4^{*}, \dagger$ & $34 \pm 5^{*}$ \\
\hline
\end{tabular}

Data were collected at the end of the respective periods and are presented as mean $\pm S D$; data are compared against baseline value within-group using a repeated measure analysis of variance (ANOVA) and between groups are made using one-way ANOVA, with the Bonferroni correction applied for multiple comparisons if significant $F$ ratios were obtained.

${ }^{*} P<0.05$ vs. baseline (within-group comparison).

$\dagger P<0.05$ vs. control (between-group comparison).

MAP, mean arterial pressure; HR, heart rate; RPP, rate pressure product; CON, control group; Repoc, remifentanil post-conditioning. 


\begin{tabular}{|c|c|c|c|c|c|}
\hline & $n$ & Baseline & $\begin{array}{l}\text { End of ischemia } \\
\text { period }\end{array}$ & $\begin{array}{l}\text { End of post-conditioning } \\
\text { period }\end{array}$ & $\begin{array}{l}\text { End of reperfusion } \\
\text { period }\end{array}$ \\
\hline CON & 6 & $99 \pm 11$ & $96 \pm 10$ & $93 \pm 10$ & $77 \pm 16^{*}$ \\
\hline NTD & 6 & $102 \pm 11$ & $101 \pm 10$ & $82 \pm 14$ & $83 \pm 17$ \\
\hline nor-BNI & 7 & $102 \pm 13$ & $102 \pm 16$ & $77 \pm 12^{*}$ & $79 \pm 14^{*}$ \\
\hline CTOP & 7 & $101 \pm 13$ & $99 \pm 12$ & $80 \pm 16$ & $81 \pm 13$ \\
\hline Ipoc +CTOP & 6 & $102 \pm 16$ & $102 \pm 11$ & $81 \pm 14$ & $81 \pm 19$ \\
\hline Repoc+NTD & 6 & $98 \pm 14$ & $97 \pm 13$ & $64 \pm 12 \dagger$ & $86 \pm 16$ \\
\hline Repoc+nor-BNI & 6 & $101 \pm 8$ & $100 \pm 9$ & $69 \pm 11^{*}, \dagger$ & $86 \pm 13$ \\
\hline Repoc+CTOP & 7 & $116 \pm 10$ & $110 \pm 13$ & $67 \pm 14^{*}, \dagger$ & $89 \pm 15^{*}$ \\
\hline \multicolumn{6}{|c|}{ HR (beats per minute) } \\
\hline CON & 6 & $423 \pm 24$ & $406 \pm 12$ & $413 \pm 18$ & $368 \pm 21^{*}$ \\
\hline Ipoc+nor-BNI & 7 & $414 \pm 14$ & $414 \pm 19$ & $380 \pm 21^{*}, \dagger$ & $375 \pm 18^{*}$ \\
\hline Ipoc+CTOP & 6 & $415 \pm 14$ & $411 \pm 14$ & $383 \pm 13^{*}, \dagger$ & $384 \pm 15$ \\
\hline Repoc+NTD & 6 & $410 \pm 29$ & $408 \pm 24$ & $371 \pm 18^{*}, \dagger$ & $382 \pm 23$ \\
\hline Repoc+nor-BNI & 6 & $421 \pm 21$ & $422 \pm 20$ & $362 \pm 5^{*}, \dagger$ & $381 \pm 20$ \\
\hline Repoc + CTOP & 7 & $420 \pm 22$ & $409 \pm 28$ & $367 \pm 15^{\star}, \dagger$ & $387 \pm 19$ \\
\hline \multicolumn{6}{|c|}{$\operatorname{RPP}(\mathrm{mmHg} / \mathrm{min} / 1000)$} \\
\hline CON & 6 & $42 \pm 4$ & $42 \pm 4$ & $38 \pm 4$ & $28 \pm 6^{*}$ \\
\hline NTD & 6 & $43 \pm 6$ & $43 \pm 6$ & $31 \pm 5 \dagger$ & $32 \pm 7$ \\
\hline nor-BNI & 7 & $42 \pm 7$ & $42 \pm 7$ & $29 \pm 6^{*}, \dagger$ & $30 \pm 6^{*}$ \\
\hline CTOP & 7 & $43 \pm 6$ & $43 \pm 6$ & $30 \pm 7^{*}, \dagger$ & $31 \pm 6^{*}$ \\
\hline Ipoc+NTD & 6 & $47 \pm 5$ & $47 \pm 5$ & $28 \pm 5^{*}, \dagger$ & $30 \pm 5^{\star}$ \\
\hline Ipoc +nor-BNI & 7 & $44 \pm 7$ & $44 \pm 7$ & $29 \pm 3^{*}, \dagger$ & $30 \pm 5^{\star}$ \\
\hline $\mathrm{Ipoc}+\mathrm{CTOP}$ & 6 & $43 \pm 8$ & $43 \pm 8$ & $31 \pm 6^{*}, \dagger$ & $31 \pm 8^{*}$ \\
\hline
\end{tabular}

Data are presented as mean \pm SD; data are compared against baseline value across different time points using a repeated measure analysis of variance (ANOVA) and between groups using one-way ANOVA, with the Bonferroni correction applied for multiple comparisons if significant $F$ ratios were obtained.

${ }^{\star} P<0.05$ vs. baseline (within-group comparison).

$\dagger P<0.05$ vs. control (between-group comparison).

MAP, mean arterial pressure; HR, heart rate; CON, control group; Ipoc, ischemic post-conditioning; Repoc, remifentanil postconditioning; NTD, naltrindole; nor-BNI, nor-binaltorphimine; CTOP, D-Phe-Cys-Tyr-D-Trp-Orn-Thr-Pen-Thr-NH ${ }_{2}$.

Repoc + CTOP also reduced LVDP at the same time point.

\section{Isolated heart IS comparisons}

The AAR ranged from $0.38 \pm 0.07$ to $0.55 \pm 0.06 \mathrm{~cm}^{3}$. The IS/AAR for both ischemic post-conditioning $(44 \pm 5 \%)$ and remifentanil post-conditioning $(42 \pm 4 \%)$ were significantly smaller relative to the control group $(59.0 \pm 3 \%)$ $(P<0.01)$. However, there was no difference in the infarct-sparing effect between the two modes of post-conditioning $(P=0.38)$. Similar to the in vivo data, the addition of NTD or nor-BNI before both ischemic and remifentanil pre-conditioning prevented their protective effects. The addition of
CTOP also had no significant effect on either post-conditioning regime. The sole administration of individual opioid receptor antagonists did not change the IS compared with the control (Fig. 4).

\section{Discussion}

The results of this study have demonstrated that the application of an exogenous opioid in the form of remifentanil after the start of the ischemic event diminishes cardiac ischemia-reperfusion injury to an extent similar to that from ischemic post-conditioning, using both the intact rat and the isolated heart perfusion model. There is an indication that the degree of protection is related to the dose 


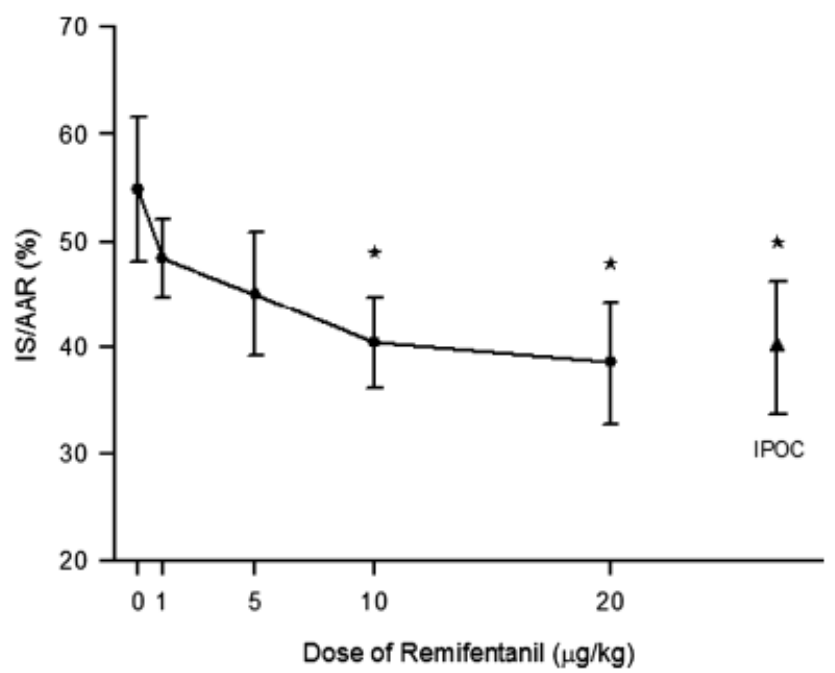

Fig. 2. Graph showing infarct size (IS) as a percentage of the area at risk (AAR) for increasing remifentanil dose. The effect of ischemic post-conditioning (Ipoc) is also shown for comparison. Results are plotted as mean \pm standard deviation. ${ }^{*} \mathrm{P}<0.05$.

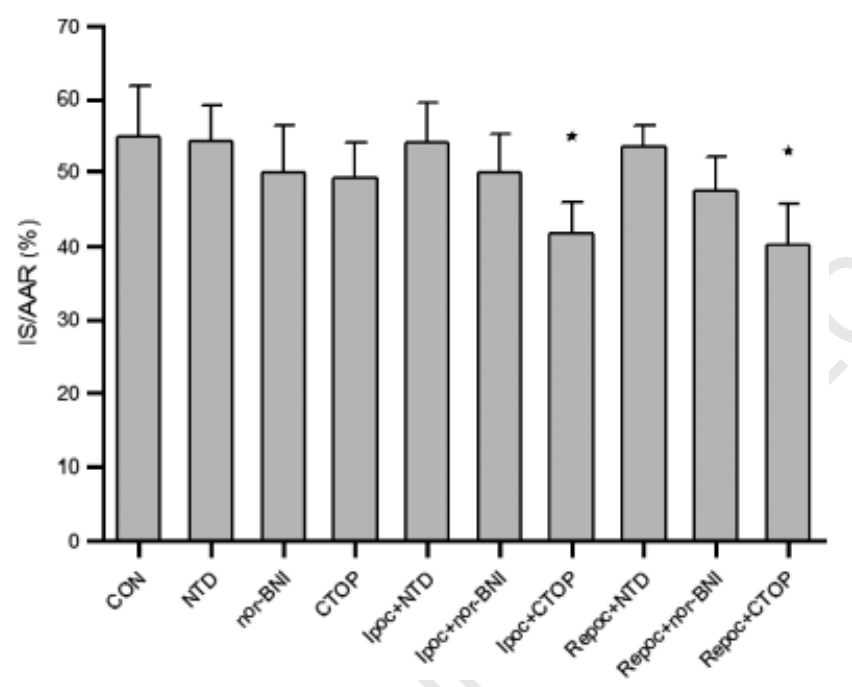

Fig. 3. Comparison of the infarct size (IS) as a percentage of the area at risk $(A A R)$ for the different treatment groups in vivo. Error bars $= \pm$ standard deviations. CON, control group; Ipoc, ischemic post-conditioning; Repoc, remifentanil post-conditioning; NTD, naltrindole; nor BNI, nor-binaltorphimine; CTOP, D-Phe-CysTyr-D-Trp-Orn-Thr-Pen-Thr-NH $\mathrm{N}_{2}{ }^{*} \mathrm{P}<0.05$ vs. control.

administered in the in vivo model. Activation of either $\delta$ or $\kappa$ opioid receptors is necessary for both forms of post-conditioning in this model. The $\mu$ receptor appears not to be involved in this process. The efficacy of post-conditioning in the isolated heart model suggests that this process is at least in part locally mediated.

Because post-conditioning was first described with the application of intermittent ischemia, a number of ligand mediators/triggers have now been identified, including adenosine, ${ }^{12,17}$ bradyki- $\operatorname{nin}^{18}$ and opioids, ${ }^{19}$ as well as reactive oxygen species. ${ }^{18}$ Although chemically diverse, a common theme underlying these compounds is that they are all increased during ischemia and reperfusion. ${ }^{20-23}$ Indeed, some have postulated that ischemic postconditioning is another form of staged or controlled reperfusion, ${ }^{24}$ possibly by altering the levels of these compounds and maintenance of an acidic $\mathrm{pH} .{ }^{17}$ Increased expression of endogenous opioids in heart tissue around the time of myocardial infarction has long been recognized ${ }^{25}$ and activation of opioid receptor subtypes may enhance ischemic tolerance. ${ }^{26}$ Activation of $\delta$ opioid receptors by morphine has been demonstrated to inhibit the mitochondria permeability transition pore, ${ }^{4}$ the putative mechanism for ischemic tolerance and, therefore, opioid post-conditioning. The significance of this study lies is not so much the demonstration of post-conditioning by an exogenous opioid per se, but in the fact that the agent is a selective $\mu$ opioid receptor agonist in clinical use and its potential clinical significance. The unique pharmacokinetic properties of remifentanil among the opioids would enable rapid attainment of high plasma concentrations without the concern of prolonged opioid-related side effects. Post-conditioning has a small window of effectiveness and rapid achievement of sufficient plasma concentration may not be attainable by other opioids with longer half-lives without resorting to using high doses. This may result in prolonged sedation and/or respiratory depression. Another point of significance on an experimental level is that remifentanil is a selective $\mu$ receptor agonist. With the exception of one study, this receptor subtype has not been implicated to be involved in post-conditioning.

In contrast to our current results with postconditioning, remifentanil mediates its preconditioning cardioprotective effect in part via $\mu$ receptors in the intact rat, ${ }^{8}$ but not in isolated rat heart preparations. ${ }^{9}$ Intrathecal morphine at a fraction of the intravenous dose can also pre-condition the heart, ${ }^{27}$ an effect attenuated by intrathecal administration of the $\mu$-specific antagonist $\mathrm{CTOP}^{28}$ These observations support a role for the activation of extra-cardiac $\mu$ receptors in remifentanil pre-conditioning. Such remote pre-conditioning has been demonstrated with other triggers such as ischemia, where pre-conditioning of one organ may confer benefits in a remote organ. ${ }^{29}$ However, whether post-conditioning, and in particular opioid postconditioning, can be remotely triggered remains to be defined. Recent work has suggested that post- 
Indices of Myocardial Performance of the isolated heart preparations.

\begin{tabular}{|c|c|c|c|c|c|c|}
\hline & $n$ & Baseline & Ischemia (30 min) & Rep (10 min) & $\operatorname{Rep}(60 \mathrm{~min})$ & $\operatorname{Rep}(120 \mathrm{~min})$ \\
\hline \multicolumn{7}{|l|}{ LVDP $(\mathrm{mmHg})$} \\
\hline Con & 6 & $100 \pm 13$ & $72 \pm 12$ & $91 \pm 14$ & $84 \pm 21$ & $73 \pm 17^{*}$ \\
\hline NTD & 6 & $97 \pm 8$ & $65 \pm 10^{*}$ & $87 \pm 7^{\star}$ & $71 \pm 6^{*}$ & $60 \pm 6^{*}$ \\
\hline CTOP & 6 & $96 \pm 11$ & $65 \pm 9^{*}$ & $85 \pm 15$ & $69 \pm 7^{*}$ & $63 \pm 4^{*}$ \\
\hline Ipoc+NTD & 6 & $98 \pm 7$ & $67 \pm 7^{*}$ & $80 \pm 7^{*}$ & $69 \pm 7^{*}$ & $62 \pm 6^{*}$ \\
\hline Ipoc+nor-BNI & 6 & $100 \pm 15$ & $62 \pm 11^{*}$ & $87 \pm 3$ & $72 \pm 11^{*}$ & $60 \pm 7^{*}$ \\
\hline Repoc+nor-BNI & 6 & $105 \pm 18$ & $67 \pm 20^{*}$ & $70 \pm 4^{*}, \dagger$ & $75 \pm 22^{*}$ & $67 \pm 18^{*}$ \\
\hline Repoc+CTOP & 6 & $111 \pm 23$ & $70 \pm 11^{*}$ & $72 \pm 9 \dagger$ & $66 \pm 10$ & $64 \pm 5^{*}$ \\
\hline \multicolumn{7}{|l|}{ LVEDP $(\mathrm{mmHg})$} \\
\hline Con & 6 & $6 \pm 2$ & $9 \pm 1$ & $34 \pm 5^{\star}$ & $21 \pm 7^{*}$ & $20 \pm 9$ \\
\hline NTD & 6 & $6 \pm 1$ & $8 \pm 2$ & $28 \pm 5^{\star}$ & $21 \pm 5^{*}$ & $16 \pm 5^{*}$ \\
\hline nor-BNI & 6 & $6 \pm 1$ & $9 \pm 1^{*}$ & $30 \pm 2^{*}$ & $23 \pm 5^{*}$ & $16 \pm 4^{*}$ \\
\hline CTOP & 6 & $7 \pm 1$ & $10 \pm 2$ & $31 \pm 7^{*}$ & $21 \pm 5^{*}$ & $17 \pm 5^{*}$ \\
\hline Repoc+nor-BNI & 6 & $5 \pm 1$ & $10 \pm 2^{*}$ & $26 \pm 4^{*}$ & $22 \pm 7^{*}$ & $15 \pm 3^{*}$ \\
\hline Repoc+CTOP & 6 & $5 \pm 1$ & $8 \pm 3$ & $28 \pm 2^{*}$ & $22 \pm 6^{*}$ & $17 \pm 4^{*}$ \\
\hline \multicolumn{7}{|c|}{ HR (beats per minute) } \\
\hline Con & 6 & $240 \pm 37$ & $251 \pm 22$ & $265 \pm 36$ & $231 \pm 50$ & $204 \pm 57$ \\
\hline NTD & 6 & $259 \pm 10$ & $255 \pm 33$ & $256 \pm 31$ & $232 \pm 26$ & $207 \pm 30$ \\
\hline nor-BNI & 6 & $253 \pm 45$ & $245 \pm 28$ & $231 \pm 31$ & $249 \pm 37$ & $216 \pm 47$ \\
\hline CTOP & 6 & $252 \pm 25$ & $267 \pm 38$ & $239 \pm 33$ & $235 \pm 39$ & $199 \pm 36$ \\
\hline Ipoc+NTD & 6 & $253 \pm 24$ & $264 \pm 21$ & $233 \pm 36$ & $211 \pm 31$ & $196 \pm 19^{*}$ \\
\hline Ipoc+nor-BNI & 6 & $266 \pm 28$ & $262 \pm 38$ & $241 \pm 26$ & $213 \pm 30$ & $205 \pm 33$ \\
\hline Ipoc+CTOP & 6 & $241 \pm 24$ & $247 \pm 25$ & $226 \pm 36$ & $219 \pm 42$ & $207 \pm 46$ \\
\hline Repoc+NTD & 6 & $237 \pm 31$ & $249 \pm 35$ & $207 \pm 48$ & $225 \pm 62$ & $194 \pm 28$ \\
\hline Repoc+nor-BNI & 6 & $246 \pm 28$ & $262 \pm 25$ & $199 \pm 22 \dagger$ & $219 \pm 16$ & $202 \pm 33$ \\
\hline Repoc +CTOP & 6 & $261 \pm 27$ & $255 \pm 22$ & $209 \pm 16^{*}$ & $237 \pm 30$ & $223 \pm 37$ \\
\hline Repoc+NTD & 6 & $2117 \pm 235$ & $1673 \pm 220^{\star}$ & $1243 \pm 95^{*}$ & $1181 \pm 90^{*}$ & $1114 \pm 77^{*}$ \\
\hline Repoc+nor-BNI & 6 & $1931 \pm 385$ & $1522 \pm 330^{\star}$ & $1246 \pm 156^{\star}$ & $1164 \pm 165^{\star}$ & $1111 \pm 131^{*}$ \\
\hline Repoc+CTOP & 6 & $2014 \pm 373$ & $1550 \pm 274^{*}$ & $1226 \pm 105^{\star}$ & $1156 \pm 90^{*}$ & $1102 \pm 90^{\star}$ \\
\hline \multicolumn{7}{|l|}{$-\mathrm{d} p / \mathrm{d} t(\mathrm{mmHg} / \mathrm{s})$} \\
\hline Con & 6 & $1601 \pm 342$ & $1363 \pm 217$ & $1178 \pm 123$ & $1061 \pm 70$ & $960 \pm 83$ \\
\hline NTD & 6 & $1447 \pm 193$ & $1272 \pm 172^{*}$ & $1168 \pm 112^{\star}$ & $1062 \pm 103^{*}$ & $989 \pm 71^{*}$ \\
\hline nor-BNI & 6 & $1559 \pm 204$ & $1316 \pm 140^{*}$ & $1241 \pm 173^{\star}$ & $1122 \pm 124^{*}$ & $997 \pm 61^{*}$ \\
\hline CTOP & 6 & $1541 \pm 348$ & $1345 \pm 240$ & $1245 \pm 185$ & $1105 \pm 149^{*}$ & $1008 \pm 98^{*}$ \\
\hline Ipoc+NTD & 6 & $1516 \pm 174$ & $1217 \pm 93$ & $1164 \pm 32$ & $1068 \pm 85^{\star}$ & $990 \pm 33^{*}$ \\
\hline Ipoc+nor-BNI & 6 & $1548 \pm 175$ & $1222 \pm 116$ & $1082 \pm 59^{*}$ & $987 \pm 48^{*}$ & $954 \pm 27$ \\
\hline Ipoc+CTOP & 6 & $1560 \pm 292$ & $1228 \pm 130$ & $1123 \pm 132$ & $1058 \pm 112^{*}$ & $969 \pm 97^{*}$ \\
\hline Repoc+NTD & 6 & $1676 \pm 334$ & $1302 \pm 174^{*}$ & $1175 \pm 164^{*}$ & $1062 \pm 160^{*}$ & $975 \pm 140^{*}$ \\
\hline Repoc+nor-BNI & 6 & $1533 \pm 212$ & $1208 \pm 63^{*}$ & $1107 \pm 68^{*}$ & $1047 \pm 98^{*}$ & $981 \pm 91^{*}$ \\
\hline Repoc+CTOP & 6 & $1617 \pm 235$ & $1344 \pm 273$ & $1148 \pm 112$ & $1064 \pm 86^{\star}$ & $1012 \pm 52^{*}$ \\
\hline
\end{tabular}

Data are presented as mean $\pm \mathrm{SD}$; data are compared against baseline value across different time points using a repeated measure analysis of variance (ANOVA) and between groups using one-way ANOVA, with the Bonferroni correction applied for multiple comparisons if significant $F$ ratios were obtained. Baseline values obtained just before induction of ischemia.

${ }^{\star} P<0.05$ vs. baseline (within-group comparison).

$\dagger P<0.05$ vs. control (between-group comparison).

LVDP, left ventricular developed pressure $(\mathrm{mmHg})$; LVEDP, left ventricular end diastolic pressure; $\mathrm{HR}$, heart rate; $\mathrm{d} P / \mathrm{d} t$, positive left ventricular pressure derivative $(\mathrm{mmHg} / \mathrm{s}) ;-\mathrm{d} P / \mathrm{d} t$, negative left ventricular pressure derivative $(\mathrm{mmHg} / \mathrm{s})$; CON, control group; Ipoc, ischemic postconditioning; Repoc, remifentanil post-conditioning; NTD, naltrindole; nor-BNI, nor-binaltorphimine; CTOP, D-Phe-CysTyr-D-Trp-Orn-Thr-Pen-Thr- $\mathrm{NH}_{2}$. 


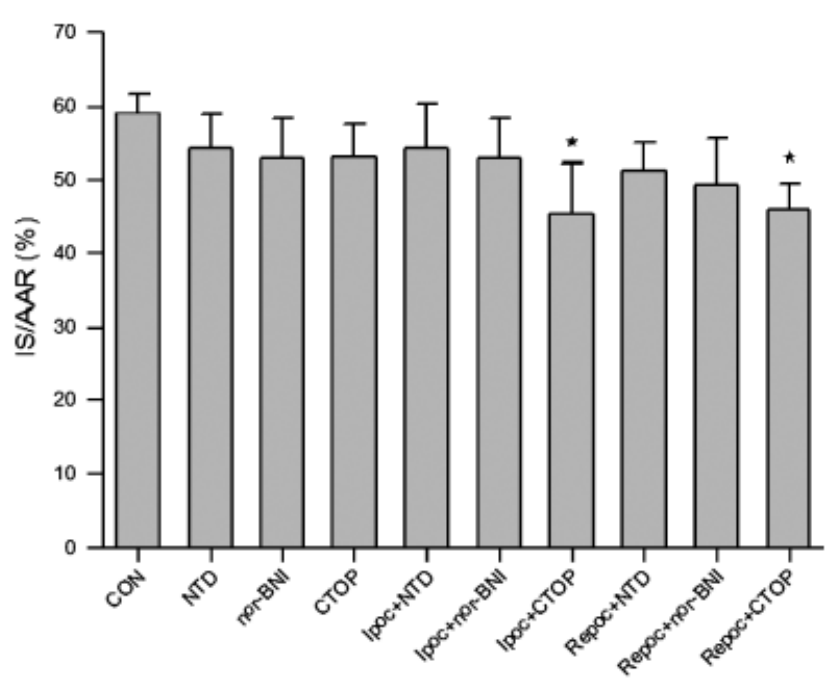

Fig. 4. Comparison of the infarct size (IS) as a percentage of the area at risk $(A A R)$ for the different treatment groups in the isolated heart preparations. Error bars $= \pm$ standard deviations. CON, control group; Ipoc, ischemic post-conditioning; Repoc, remifentanil post-conditioning; NTD, naltrindole; nor BNI, nor-binaltorphimine; CTOP, D-Phe-Cys-Tyr-D-Trp-Orn-Thr-Pen-Thr-NH H $^{*} \mathrm{P}<0.05$ vs. control.

conditioning may be remotely triggered by inducing ischemia in a distant organ. ${ }^{30}$ It is not possible to infer from our results whether remifentanil postconditioning is an entirely locally and/or remotely triggered as the results are similar both in the intact animal and in the isolated rat.

Most previous observations regarding the relative roles of opioid receptors in post-conditioning have implicated the $\delta$ and $\kappa$ receptors, ${ }^{4,5,31}$ as our current data also suggest. Our observations, however, are inconsistent with those from Zatta et al., ${ }^{5}$ where the investigators demonstrated that the effects of ischemic post-conditioning may be inhibited by the $\mu$ opioid receptor antagonist CTAP at a dose between 0.09 and $0.19 \mathrm{umol} / \mathrm{kg}$. The dose of $1 \mathrm{mg} / \mathrm{kg}(0.94 \mu \mathrm{mol} / \mathrm{kg})$ of CTOP used in this study is higher on a molar basis than the dose of CTAP used by Zatta and colleagues and thus the difference cannot be account for by an insufficient dose. Further inconsistencies are also seen with the $\delta$ receptor in post-conditioning. A study evaluating morphine post-conditioning in the isolated heart model demonstrated that its protective effect was not attenuated by the $\delta$ receptor antagonist NTD. ${ }^{32}$ This finding contrasts with previous work where a specific $\delta$ agonist was effective in producing postconditioning benefits. ${ }^{19}$ Therefore, the relative roles of opioid receptors in post-conditioning will require further definition, as it will influence the choice of the exogenous opioid used.
Cardiac post-conditioning has led to exciting prospects for clinical cardiac protection as it removes the Achilles' heel of pre-conditioning, that of timing the intervention before the index ischemic event. Pharmacological post-conditioning can potentially further circumvent the limitations posed by ischemic post-conditioning in the clinical setting. The iatrogenic induction of myocardial ischemia could harm the diseased coronaries or may be arrhythmogenic. Pharmacological postconditioning may be more versatile as it can easily be applied in the post-cardiopulmonary bypass setting, in patients undergoing thrombolysis as well as coronary angioplasty. Should opioid postconditioning be shown to be clinically beneficial, remifentanil would indeed be a logical choice for this purpose.

In conclusion, data from this study have confirmed the efficacy of remifentanil post-conditioning as being equal to that of ischemic post-conditioning and both involve the activation of $\kappa$ and $\delta$ receptors. It would be interesting to determine the subcellular mechanisms involved in remifentanil post-conditioning to see whether they are common to those elicited by other opioids, ligands or ischemia. Should obvious differences be apparent, consideration may be made to a multimodal approach to post-conditioning, much analogous to the wellproven practice of multimodal analgesia.

\section{Acknowledgements}

This work was performed in the Department of Anaesthesiology, University of Hong Kong, and was funded in part by the Small Project Fund, University of Hong Kong. It has been presented in part at the Annual Scientific Meeting of the Australian and New Zealand College of Anaesthetists in Sydney, Australia, on 6 May 2008.

\section{References}

1. Zhao ZQ, Corvera JS, Halkos ME, Kerendi F, Wang NP, Guyton RA, Vinten-Johansen J, Zhao Z-Q, Corvera JS, Halkos ME, Kerendi F, Wang N-P, Guyton RA, VintenJohansen J. Inhibition of myocardial injury by ischemic postconditioning during reperfusion: comparison with ischemic preconditioning. Am J Physiol Heart Circ Physiol 2003; 285: H579-88.

2. Hausenloy DJ, Tsang A, Yellon DM, Hausenloy DJ, Tsang A, Yellon DM. The reperfusion injury salvage kinase pathway: a common target for both ischemic preconditioning and postconditioning. Trends Cardiovasc Med 2005; 15: 69-75.

3. Kin H, Zatta AJ, Jiang R, Reeves JG, Mykytenko J, Sorescu G, Zhao Z-QKin H, Zatta AJ, Jiang R, Reeves JG, Mykytenko I, Sorescu G, Zhao Z-Q, Guyton RA, Vinten-Johansen $I_{\Omega}$ Activation of opioid receptors mediates the infarct size 
reduction by postconditioning. J Mol Cell Cardiol 2005; 38: 827.

4. Jang $\mathrm{Y}, \mathrm{Xi}$ J, Wang H, Mueller RA, Norfleet EA, Xu Z. Postconditioning prevents reperfusion injury by activating delta-opioid receptors. Anesthesiology 2008; 108: 243-50.

5. Zatta AJ, Kin H, Yoshishige D, Jiang R, Wang N, Reeves JG, Mykytenko J, Guyton RA, Zhao ZQ, Caffrey JL, VintenJohansen J, Zatta AJ, Kin H, Yoshishige D, Jiang R, Wang N, Reeves JG, Mykytenko J, Guyton RA, Zhao Z-Q, Caffrey JL, Vinten-Johansen J. Evidence that cardioprotection by postconditioning involves preservation of myocardial opioid content and selective opioid receptor activation. Am J Physiol Heart Circ Physiol 2008; 294: H1444-51.

6. Ventura C, Bastagli L, Bernardi P, Caldarera CM, Guarnieri C. Opioid receptors in rat cardiac sarcolemma: effect of phenylephrine and isoproterenol. Biochim Biophys Acta 1989; 987: 69-74.

7. Head BP, Patel HH, Roth DM, Lai NC, Niesman IR, Farquhar MG, Insel PA. G-protein-coupled receptor signaling components localize in both sarcolemmal and intracellular caveolin-3-associated microdomains in adult cardiac myocytes. J Biol Chem 2005; 280: 31036-44.

8. Zhang Y, Irwin MG, Wong TM. Remifentanil preconditioning protects against ischemic injury in the intact rat heart. Anesthesiology 2004; 101: 918-23.

9. Zhang Y, Irwin MG, Wong TM, Chen M, Cao CM. Remifentanil preconditioning confers cardioprotection via cardiac kappa- and delta-opioid receptors. Anesthesiology 2005; 102: 371-8.

10. Hausenloy DJ, Yellon DM, Hausenloy DJ, Yellon DM. Preconditioning and postconditioning: united at reperfusion. Pharmacol Ther 2007; 116: 173-91.

11. Yu CK, Li YH, Wong GT, Wong TM, Irwin MG. Remifentanil preconditioning confers delayed cardioprotection in the rat. Br J Anaesth 2007; 99: 632-8.

12. Kin H, Zatta AJ, Lofye MT, Amerson BS, Halkos ME, Kerendi F, Zhao ZQ, Guyton RA, Headrick JP, VintenJohansen J. Postconditioning reduces infarct size via adenosine receptor activation by endogenous adenosine. Cardiovasc Res 2005; 67: 124-33.

13. Kin H, Zhao ZQ, Sun HY, Wang NP, Corvera JS, Halkos ME, Kerendi F, Guyton RA, Vinten-Johansen J. Postconditioning attenuates myocardial ischemia-reperfusion injury by inhibiting events in the early minutes of reperfusion. [see comment]. Cardiovasc Res 2004; 62: 74-85.

14. Portoghese PS, Sultana M, Takemori AE. Naltrindole, a highly selective and potent non-peptide delta opioid receptor antagonist. Eur J Pharmacol 1988; 146: 185-6.

15. Hawkins KN, Knapp RJ, Lui GK, Gulya K, Kazmierski W, Wan YP, Pelton JT, Hruby VJ, Yamamura HI. [3 H]-[H-DPhe-Cys-Tyr-D-Trp-Orn-Thr-Pen-Thr- $\left.\mathrm{NH}_{2}\right]$ ([3 H]CTOP), a potent and highly selective peptide for mu opioid receptors in rat brain. J Pharmacol Exp Ther 1989; 248: 73-80.

16. Portoghese PS, Lipkowski AW, Takemori AE. Binaltorphimine and nor-binaltorphimine, potent and selective kappaopioid receptor antagonists. Life Sci 1987; 40: 1287-92.

17. Cohen MV, Yang XM, Downey JM, Cohen MV, Yang X-M, Downey JM. The $\mathrm{pH}$ hypothesis of postconditioning: staccato reperfusion reintroduces oxygen and perpetuates myocardial acidosis. Circulation 2007; 115: 1895-903.

18. Penna C, Mancardi D, Rastaldo R, Losano G, Pagliaro P. Intermittent activation of bradykinin B2 receptors and mitochondrial KATP channels trigger cardiac postconditioning through redox signaling. Cardiovasc Res 2007; 75: 168-77.

19. Gross ER, Hsu AK, Gross GJ. Opioid-induced cardioprotection occurs via glycogen synthase kinase $\{$ beta\} inhibition during reperfusion in intact rat hearts. Circ Res 2004; 94: 960-6.

20. Ely SW, Berne RM. Protective effects of adenosine in myocardial ischemia. Circulation 1992; 85: 893-904.

21. Pan H-L, Chen S-R, Scicli GM, Carretero OA. Cardiac interstitial bradykinin release during ischemia is enhanced by ischemic preconditioning. Am J Physiol Heart Circ Physiol 2000; 279: H116-21.

22. Barron BA. Cardiac opioids. Proc Soc Exp Biol Med 2000; 224: $1-7$.

23. Becker LB, vanden Hoek TL, Shao Z-H, Li C-Q, Schumacker PT. Generation of superoxide in cardiomyocytes during ischemia before reperfusion. Am J Physiol Heart Circ Physiol 1999; 277: H2240-6.

24. Heusch G. Postconditioning: old wine in a new bottle? J Am Coll Cardiol 2004; 44: 1111-2.

25. Paradis P, Dumont M, Belichard P, Rouleau JL, Lemaire S, Brakier-Gingras L. Increased preproenkephalin A gene expression in the rat heart after induction of a myocardial infarction. Biochem Cell Biol 1992; 70: 593-8.

26. Romano MA, Seymour EM, Berry JA, McNish RA, Bolling SF. Relative contribution of endogenous opioids to myocardial ischemic tolerance. J Surg Res 2004; 118: 32-7.

27. Groban L, Vernon JC, Butterworth J. Intrathecal morphine reduces infarct size in a rat model of ischemia-reperfusion injury. Anesth Analg 2004; 98: 903-9.

28. Li R, Wong GT, Wong TM, Zhang Y, Xia Z, Irwin MG. Intrathecal morphine preconditioning induces cardioprotection via activation of delta, kappa, and mu opioid receptors in rats. Anesth Analg 2009; 108: 23-9.

29. Walsh SR, Tang T, Sadat U, Dutka DP, Gaunt ME. Cardioprotection by remote ischaemic preconditioning. $\mathrm{Br} \mathrm{J}$ Anaesth 2007; 99: 611-6.

30. Andreka G, Vertesaljai M, Szantho G, Font G, Piroth Z, Fontos G, Juhasz ED, Szekely L, Szelid Z, Turner MS, Ashrafian H, Frenneaux MP, Andreka P. Remote ischaemic postconditioning protects the heart during acute myocardial infarction in pigs. Heart 2007; 93: 749-52.

31. Wang J, Gao Q, Lu Y, Xia Q. Kappa opioid receptor mediates the cardioprotection of postconditioning in the isolated rat heart subjected to ischemia and reperfusion. FASEB J 2006; 20: A742-c-.

32. Chen Z, Li T, Zhang B. Morphine postconditioning protects against reperfusion injury in the isolated rat hearts. J Surg Res 2008; 145: 287-94.

\section{Address:}

Dr Gordon T. C. Wong

Department of Anaesthesiology

University of Hong Kong

Room 424

K Block

Queen Mary Hospital

Pokfulam Road

Hong Kong

e-mail: gordon@hkucc.hku.hk 


\section{Author Query Form}

\begin{tabular}{ll}
\hline Journal & AAS \\
Article & 2145
\end{tabular}

Dear Author,

During the copy-editing of your paper, the following queries arose. Please respond to these by marking up your proofs with the necessary changes/additions. Please write your answers clearly on the query sheet if there is insufficient space on the page proofs. If returning the proof by fax do not write too close to the paper's edge. Please remember that illegible mark-ups may delay publication.

\begin{tabular}{|c|l|c|}
\hline Query No. & \multicolumn{1}{|c|}{ Description } & Author Response \\
\hline Q1 & $\begin{array}{l}\text { AUTHOR: Please provide forename for author 'N-P W', and also if this is not a one-page article please supply the } \\
\text { first and last pages for reference [3]. }\end{array}$ & \\
\hline Q2 & AUTHOR: If this is not a one-page article please supply the first and last pages for reference [31]. & \\
\hline Q3 & $\begin{array}{l}\text { Figure 2, 3 and 4 of poor quality. Please check required artwork } \\
\text { specifications at } \leq \text { http://WWW.blackwellpublishing.com/authors/digill.asp }>\end{array}$ & \\
\hline & & \\
\hline & & \\
\hline
\end{tabular}




\section{USING E-ANNOTATION TOOLS FOR ELECTRONIC PROOF CORRECTION}

\section{Required Software}

Adobe Acrobat Professional or Acrobat Reader (version 7.0 or above) is required to e-annotate PDFs. Acrobat 8 Reader is a free download: http://www.adobe.com/products/acrobat/readstep2.html

Once you have Acrobat Reader 8 on your PC and open the proof, you will see the Commenting Toolbar (if it does not appear automatically go to Tools>Commenting>Commenting Toolbar). The Commenting Toolbar looks like this:

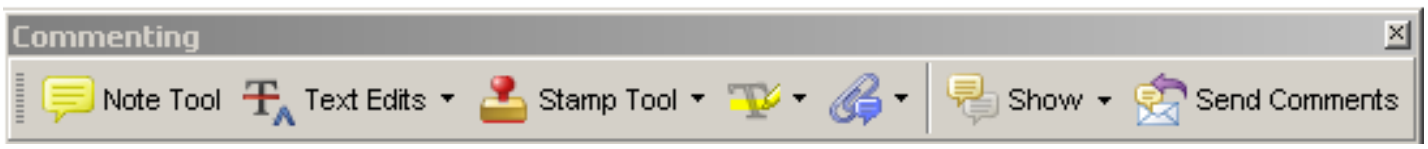

If you experience problems annotating files in Adobe Acrobat Reader 9 then you may need to change a preference setting in order to edit.

In the "Documents" category under "Edit - Preferences", please select the category 'Documents' and change the setting "PDF/A mode:" to "Never".

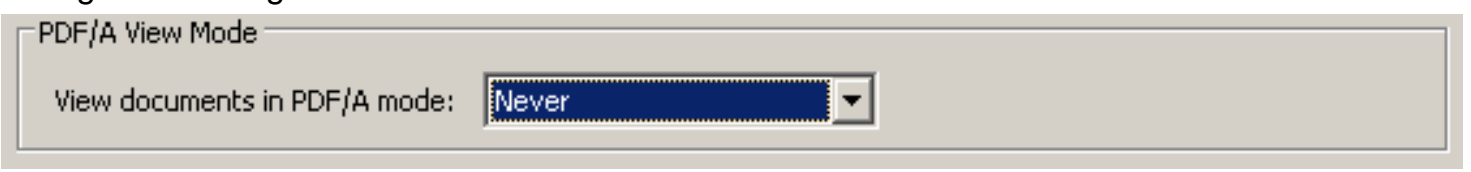

\section{Note Tool - For making notes at specific points in the text}

Marks a point on the paper where a note or question needs to be addressed.

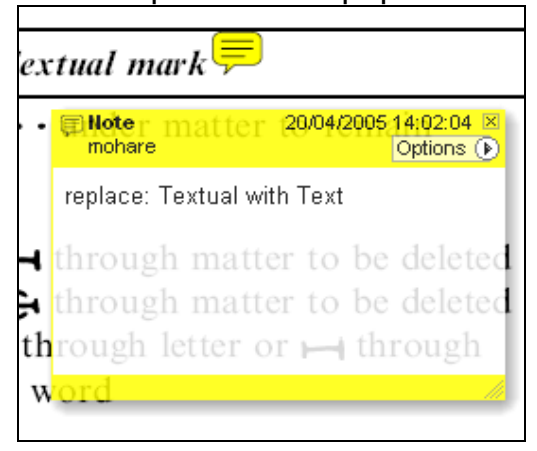

\section{How to use it:}

1. Right click into area of either inserted text or relevance to note

2. Select Add Note and a yellow speech bubble symbol and text box will appear

3. Type comment into the text box

4. Click the $X$ in the top right hand corner of the note box to close.

\section{Replacement text tool - For deleting one word/section of text and replacing it}

Strikes red line through text and opens up a replacement text box.

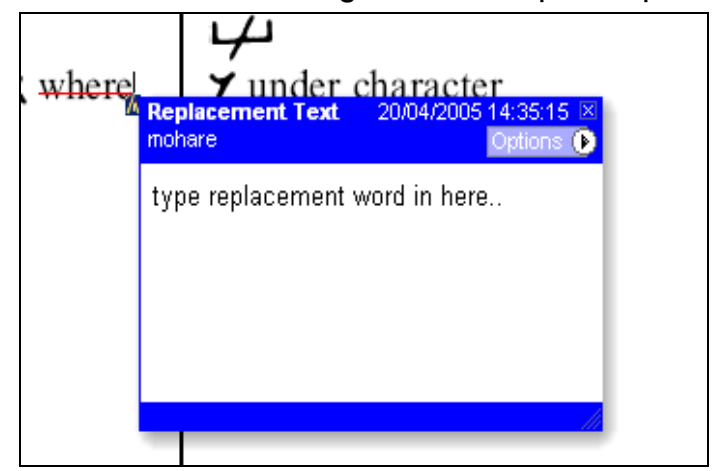
How to use it:
1. Select cursor from toolbar
2. Highlight word or sentence
3. Right click
4. Select Replace Text (Comment) option
5. Type replacement text in blue box
6. Click outside of the blue box to close

\section{Cross out text tool - For deleting text when there is nothing to replace selection}

Strikes through text in a red line.

\begin{tabular}{|l|}
\hline substitute part of one or \\
more word(s) \\
Change to italies \\
Change to capitals \\
Change to small capitals \\
\hline
\end{tabular}
How to use it:
1. Select cursor from toolbar
2. Highlight word or sentence
3. Right click
4. Select Cross Out Text 


\section{WILEY-BLACKWELL}

Approved tool - For approving a proof and that no corrections at all are required.

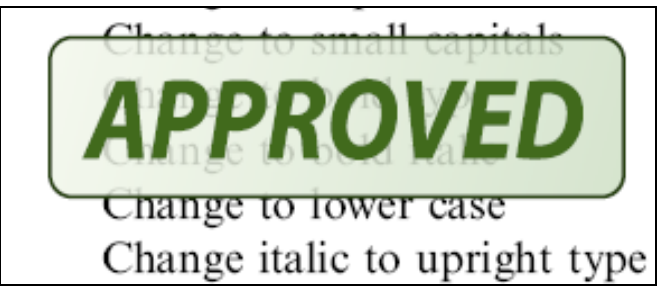

\section{How to use it:}

1. Click on the Stamp Tool in the toolbar

2. Select the Approved rubber stamp from the 'standard business' selection

3. Click on the text where you want to rubber stamp to appear (usually first page)

Highlight tool - For highlighting selection that should be changed to bold or italic. Highlights text in yellow and opens up a text box.

\begin{tabular}{|c|c|}
\hline & \\
\hline puble quotation & (As above) \\
\hline phen $\begin{array}{c}\text { Highlight } \\
\text { mohare }\end{array}$ & $\begin{array}{l}\text { 20:04:2005 14:45:47 } x \\
\text { Options (i) }\end{array}$ \\
\hline W par & \\
\hline parą & \\
\hline $\mathrm{se}$ & \\
\hline 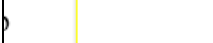 & \\
\hline ace $b$ & \\
\hline
\end{tabular}

\section{How to use it:}

1. Select Highlighter Tool from the commenting toolbar

2. Highlight the desired text

3. Add a note detailing the required change

Attach File Tool - For inserting large amounts of text or replacement figures as a files. Inserts symbol and speech bubble where a file has been inserted.

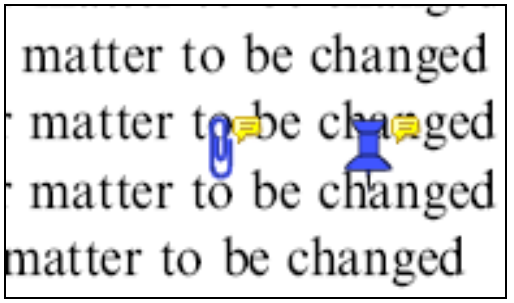

How to use it:

1. Click on paperclip icon in the commenting toolbar

2. Click where you want to insert the attachment

3. Select the saved file from your PC/network

4. Select appearance of icon (paperclip, graph, attachment or tag) and close

\section{Pencil tool - For circling parts of figures or making freeform marks}

Creates freeform shapes with a pencil tool. Particularly with graphics within the proof it may be useful to use the Drawing Markups toolbar. These tools allow you to draw circles, lines and comment on these marks.

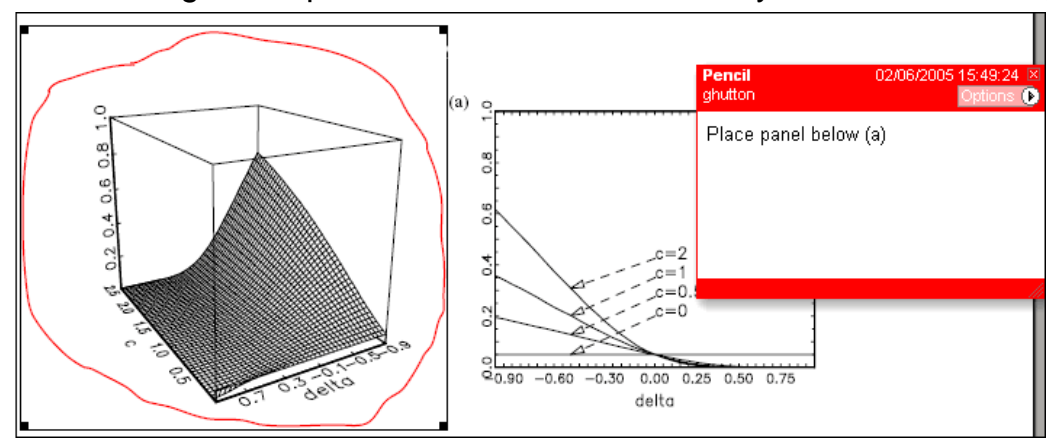

How to use it:

1. Select Tools $>$ Drawing Markups $>$ Pencil Tool

2. Draw with the cursor

3. Multiple pieces of pencil annotation can be grouped together

4. Once finished, move the cursor over the shape until an arrowhead appears and right click

5. Select Open Pop-Up Note and type in a details of required change

6. Click the $X$ in the top right hand corner of the note box to close. 
Help

For further information on how to annotate proofs click on the Help button to activate a list of instructions:

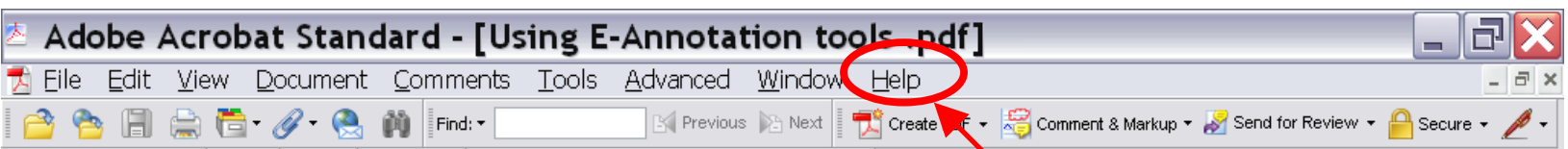

